\title{
UNDERSTANDING HOW INFRASTRUCTURE INTERACT WITH THE RECLAIMED LANDS HAVING EARTHQUAKE INDUCED LIQUEFACTION VULNERABILITY
}

\author{
Md Kabir Uddin Sikder \\ Department of Civil Engineering \\ Military Institute of Science and Technology (MIST) \\ Dhaka, Bangladesh
}

\begin{abstract}
The paper aims at evaluating the interaction between infrastructure like bridges, buildings, slopes, roads, and foundation with reclaimed land with earthquake induced liquefaction vulnerability. The assessment begins by providing an overview of the study topic by introducing the areas under study and giving its background information. The researcher carried out a secondary data through the analysis of the existing information on the interaction between infrastructure like bridges, buildings, slopes, roads, and foundation with reclaimed land with earthquake induced liquefaction vulnerability. The primary data collection method used was interviewing, and the chosen area of study was the Northeastern part of Bangladesh with a focus on Sylhet and Mouluvibazar. Observation and photographing were also used a primary data collection method. Tests were also carried out by the use of Cone Penetrator Tests (CPTs) to offer data for soil types and soil layers. The finding of the study was that lateral spreading of the soil around the liquefaction lines, slopes, and areas where the arrangements apply pressure. The other result was that fissuring on the ground surface causes railroads and tarmac roads to break. From the study outcome, it was concluded that structures erected on reclaimed lands that have earthquake-induced liquefaction vulnerability are at risk of being destroyed at any time in case of lack of a preventive measure.
\end{abstract}

Keywords- Reclaimed Lands, Earthquake Induced, Liquefaction Vulnerability.

\section{INTRODUCTION}

Liquefaction is a situation whereby a soil's stiffness and strength is lessened by an earthquake shaking. When it occurs, the capability of the ground to hold foundations, buildings, roads, slopes, and bridges is reduced. Reclaimed land is very prone to liquefaction because of the weak held soils. Earthquake liquefaction is at this moment the procedure where unconsolidated and saturated soil is transformed to a suspension after an earthquake occurs (Prevost, 1985). It has a devastating impact on structures in the areas with such soils. Liquefied soils do not have the capability of holding structures (Bird \& Bommer, 2004). It is, therefore, necessary to analyze the respective reclaimed lands to discover the liquefability of the grounds in that area. It could occur by the cone penetrometer test, an in-situ analysis, and laboratory examination of the porosity, drainage, and types of soil. This paper aims to investigate how infrastructure interacts with reclaimed lands with earthquake-induced liquefaction vulnerability.

The rest of the paper is organized as follows. Background information is explained in section II. Research Methodology is described in section III. Experimental results are presented in section IV. Discussion and recommendations are explained in section V and VI respectively. Concluding remarks are given in section VII.

\section{BACKGROUND INFORMATION}

According to a case study conducted on New Zealand's West Coast on the Hawks Crag events (1991), the Inangahua earthquake (1968), and the Murchison earthquake (1929), liquefaction takes place in soils where water fills the spaces between the individual particles (Bhattacharya et al., 2011). The tightness of how the soil particles are packed together depends on the pressure this water exerts on them (Verdugo, 1989). The earthquake shake may also cause the weight of the water to increase to an extent where the particles move in unison (Elgamal A. 2007). Identifying areas experiencing liquefaction was primarily done by conducting studies on areas with sinking and tilting structures, lateral spreading, sand boils, subsidence of the ground surface and areas ejecting mud and water from underground.

According to research by the University of Cambridge, the Kobe earthquake of 1995 and the Christchurch calamity is the recent occurrence of the vulnerability of reclaimed lands to 


\section{International Journal of Engineering Applied Sciences and Technology, 2019 \\ Vol. 4, Issue 2, ISSN No. 2455-2143, Pages 16-19 \\ Published Online June 2019 in IJEAST (http://www.ijeast.com)}

liquefaction (Yang et al., 2003). Liquefaction took place in the coastal areas of Kobe city where the grounds were reclaimed, causing massive ground deformations, foundation failure, and slumping of revetment lines. A significant observation from that earthquake in areas treated by soil improvement processes experienced low levels of liquefaction and ground deformation.

\section{RESEARCH METHODOLOGY}

For this research, a comprehensive method that involves sampling the areas for research, analyzing them, and conduction interviews to get more information and for clarifications. Sampling method was applied such that after consultations, few areas that experienced liquefaction were picked up for the study. The researchers chose the Northeastern part of Bangladesh with a focus on Sylhet and Mouluvibazar district that had experienced an earthquake of 5.4-magnitude on the Richter scale in 2018. They further narrowed down to Jaflong and Jaintapur in the north.

Interviews, being a primary technique, were later on conducted. They are essential for the researchers obtained first-hand information. They also give a profound experience of specific people through, listening to what they experienced. Interviews were conducted on the professional engineers and earthquake experts concerning the effects of this liquefaction soils on the reclaimed lands, occupants of the structures that were destroyed on the reclaimed areas with earthquakeinduced liquefaction vulnerability. From this, the researchers were able to get information on how it felt like during the calamities. The engineers provided more in-depth explanations and clarifications on various issues that the researchers found challenging.

In identifying whether a site is liquefaction or nonliquefaction, an analysis was conducted. The study commenced with a preliminary site investigation of the reclaimed lands affected by earthquakes. This was done after the Sylhet earthquake of 2018 , whereby photographs were taken for evidence and help got from some of the residents. Hand augering should then follow to make sure that there is no layer of gravel to inhibit Cone Penetrometer Tests (CPTs). A CPT provided a broad interpretation of the soil layers and soil types. It was attempted in the Jaintapur area where at first was unsuccessful because of the layers of gravel. Flight augers were later on used to drill through the gravel enabling CPT to be made. The analysis of the reclaimed lands using the CPT tests is critical determining the soil types and soil profiles and thus establishing the cohesiveness of the soil particles, which gives the soil strength to support structures.

After the CPT tests different analysis methodologies were used to determine the probability of liquefaction occurrences on a site as seen in table 1 below:

Table 1: Analysis methods used to compute data from the CPT tests

\begin{tabular}{ll}
\hline $\begin{array}{l}\text { Stress Based Prediction } \\
\text { Methods }\end{array}$ & $\begin{array}{l}\text { Energy Based Prediction } \\
\text { Methods }\end{array}$ \\
\hline $\begin{array}{l}\text { Shibata and Teparaksa [11] } \\
\text { Suzuki, Tokimatsu, Koyamada, } \\
\text { Taya and Kubota }\end{array}$ & Davis and Berrill [18] \\
Olsen [13] & Liao,Veneziano and Whitman \\
& [19] \\
Robertson and Wride [14] as & Lae, Cao and He [20]
\end{tabular}

NCEER [22]

Juang, Yuan, Lee, Lin [15]

Topark and Holzer (2003)

Source: (Bhattacharya et al., 2011).

Peak ground accelerations values were then calculated at each of the chosen sites for the 2018 Sylhet earthquake as indicated on table 2 below:

Table 2: Peak ground accelerated values

\begin{tabular}{|lccc|}
\hline Location & \multicolumn{3}{c|}{ 2018 Sylhet (M 5.4) } \\
\hline Jaflong & Recorded & Calculated & Used \\
Jaintapur & $0.228 \mathrm{~g}$ & $0.228 \mathrm{~g}$ & $0.228 \mathrm{~g}$ \\
Lala Khal & $0.202 \mathrm{~g}$ & $0.182 \mathrm{~g}$ & $0.182 \mathrm{~g}$ \\
Purba & $0.142 \mathrm{~g}$ & $0.142 \mathrm{~g}$ & $0.142 \mathrm{~g}$ \\
Nijpat & $0.158 \mathrm{~g}$ & $0.110 \mathrm{~g}$ & $0.110 \mathrm{~g}$ \\
Darbasta & $0.058 \mathrm{~g}$ & $0.058 \mathrm{~g}$ & $0.058 \mathrm{~g}$
\end{tabular}

The tests for each of the sites were then compiled to give results of the CPT test. Below is a table of the results for the examinations conducted in Sylhet. The first chart shows friction ratios and measured tip resistance together with values obtained by the methods of Bhattacharya et al. (2011). The second one shows a rate of measured resistance to critical tip resistance defined as $F S=C R R / C S A$. The last chart shows layers that are potentially liquefiable regarding the prediction methods as seen from figure 1 below.

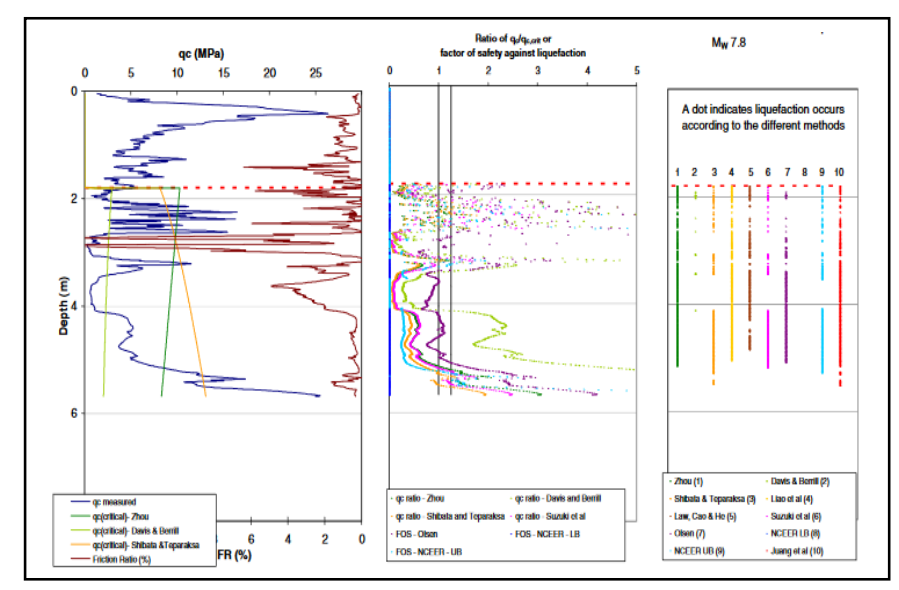




\section{International Journal of Engineering Applied Sciences and Technology, 2019 \\ Vol. 4, Issue 2, ISSN No. 2455-2143, Pages 16-19 \\ Published Online June 2019 in IJEAST (http://www.ijeast.com)}

Fig. 1. Cone Penetrometer Test results and results for the Sylhet area of Bangladesh

\section{RESULTS}

After the various measures were put in place, the researchers compiled their results that included the causes and remedies in a report. From the research, they came up with findings of how reclaimed land with earthquake-induced liquefaction interacts with infrastructure as follows; Buckling of pile foundations of the different structure such as buildings and bridges. Lateral spreading of the soil around the liquefaction lines, slopes, and areas where the arrangements apply pressure. Fissuring on the ground surface causes railroads and tarmac roads to break (Bhattacharya et al., 2011). Tilting of fabrics that are directly above the liquefaction lines as a result of weak and loosely held soils, and Landslides on the steep slopes associated with loose soils that cause the infrastructure to crumble and be destroyed.

\section{DISCUSSION}

Buckling of piles: pile foundations are erected deep in the ground, this because of the support of the soil (Tsuchida, 1970). Once the soil gets liquefied by an earthquake, the pile should be treated as a freestanding one because the ground will now not be able to give the required lateral strength to the collection. Piles located in such grounds are supposed to be designed for Euler's buckling that makes sure safety to piles during an earthquake (Seed \& Lee, 1966). A slender pile is more susceptible to buckling than a non-slender one; hence, it is advised to use a few collections with bigger diameters in liquefiable soil.

Lateral spreading: this is the lateral movement of saturated soils on steep or gentle slopes, brought about by earthquakeinduced liquefaction. This movement can be from centimeters to meters hence causing damages on infrastructure. The chemistry behind the lateral movement is when the pore water pressure in the soil reduces the stiffness and strength of them, making them weak. The piles supporting the above structures, therefore, become vulnerable to lateral movement. From the Jaintapur earthquake, the bridge on the Lala Khal became arched, the collections got fractured, and their piers destroyed as a result of lateral movement (Goda et al., 2016). The abutments of the deck pinning suffered back-rotation, and the top of the abutment piles was damaged. Falling of power poles and rupturing of water pipes was also evident.

Fissuring: this is when cracks form on the ground surface. In Jaflong, land reclamation occurred by using long-shore deposition and sand trapped by strong groin feature, experienced fissures. There were cracks on the roads which were characterized by breakwaters emanating from the ground
(Huang \& Jiang 2010). Findings also showed that the structures that had their foundations intersecting the liquefaction zone underwent massive destruction than the other adjacent structures, and even flat areas and areas with horizontal non-uniform liquefiable soils experienced large fissures.

\section{RECOMMENDATIONS}

Luckily, these reclaimed lands can be fashioned to become safer for infrastructure by; improving the condition of the soil. This occurs by adjusting the soil's drainage capacity to avoid an increase in the pore water pressure during an earthquake. Ways of improving the condition of the land include dynamic compaction whereby a heavy concrete or steel dropped from a high place of between 40 to 100 feet. This system is economical although the soil surface may, later on, need slight compaction. Drainage techniques can also be used to improve the condition of the soil such that drains of sand, gravel, and synthetic materials may be installed to get rid of the pore water. Compaction grouting is also very appropriate where a mortar is directly forced into the granular soil, forming a bulb that will densify the soil. Engineers may also consider vibroflotation, use of stone columns, and use of compaction piles. Apart from improving the condition of the ground, using a liquefaction-proof system in these reclaimed lands makes it safer for the structures and their users. One method is erecting structures that are ductile and can endure large deformations, using a foundation design that can reduce the number of damages, and using adjustable supports.

\section{CONCLUSIONS}

From the facts from the research paper above it is evident that structures erected on reclaimed lands that have earthquake-induced liquefaction vulnerability are at risk of being destroyed at any time in case of lack of a preventive measure. That may be caused by landslides, buckling of the pile foundations, fissuring and lateral movement of the soils supporting the foundations of the structures. It is, therefore, necessary to analyse the respective reclaimed lands to discover the liquefability of the grounds in that area. It could occur by the cone penetrometer test, an in-situ analysis, and laboratory examination of the porosity, drainage, and types of soil.

\section{REFERENCE}

[1] Bhattacharya S., Hyodo M., and Goda K. (2011), "Liquefaction of soil in the Tokyo Bay area from the 2011 Tohoku (Japan) earthquake". Soil Dynamics and Earthquake Engineering 31 (11), (pp. 1618-1628).

[2] Bird J. F., and Bommer J. J. (2004), "Evaluating Earthquake Losses Due to Ground Failure and Identifying 
their Relative Contribution". 13th World Conference on Earthquake Engineering Vancouver, B.C., Canada, Paper No. 3156.

[3] Elgamal A. (2007), "Nonlinear modeling of large-scale ground foundation-structure seismic response". ISET J. Earthquake Technology, 44(2), (pp. 325-339).

[4] Goda K., Campbell G., Hulme L., Ismael B., Ke L., Marsh R., Sammonds P., So E., Okumura Y. and Kishi N. (2016), "The 2016 Kumamoto earthquakes: cascading geological hazards and compounding risks". Frontiers in Built Environment, 2, (pp. 19).

[5] Huang Y. and Jiang X. (2010), "Field-observed phenomena of seismic liquefaction and subsidence during the 2008 Wenchuan earthquake in China". Natural Hazards, 54(3), (pp. 839-850).

[6] Prevost J.H. (1985), "A simple plasticity theory for frictional cohesionless soils". International Journal of Soil Dynamics and Earthquake Engineering, 4(1), (pp. 9-17).

[7] Seed H. B. and Lee K. L. (1966), "Liquefaction of saturated sands during cyclic loading". Journal of the Soil Mechanics and Foundations Division, 92(6), (pp. 105134).

[8] Tsuchida H. (1970), " Prediction and countermeasure against the liquefaction in sand deposits". Abstract of the seminar in the Port and Harbor Research Institute, (pp 3.1-3.33)

[9] Verdugo R. (1989), "Effect of fine content on the steady state of deformation on sandy soils". Master thesis, University of Tokyo.

[10] Yang Z., Elgamal A. and Parra E. (2003), “Computational model for cyclic mobility and associated shear deformation". Journal of Geotechnical and Geoenvironmental Engineering, 129(12), (pp. 11191127). 